\title{
Determinants of Export Performance of Manufacturing Industries in Dire Dawa
}

\author{
Gezate Gete (MA) \\ Department of Logistics and supply Chain Management College of Business and Economics Dere Dawa \\ University
}

\begin{abstract}
The overall purpose of this study was to identify determinants of export performance of manufacturing industries in Dire Dawa city Administration. The research incorporated both primary and secondary data. The primary data was collected through self-administered questionnaire whereas secondary data were extracted under a comprehensive desk review of the manufacturing sector policies, performance, status, problems etc. and reviewed mainly from published journal articles and books. Descriptive research design research method was utilized to identify the determinants of export performance of manufacturing industries in Dire Dawa city Administration and quantitative and qualitative information was taken into account. To process the collected data analysis SPSS version 20 was used. The study found that building of physical capital, raw material supplies, logistics and transportation, educated and skilled work force, loan from banks, rate of exchange, incentives, use of the internet, productivity improvement, value addition, and diversification, unit prices, differentiation, branding, retailing, ease of doing Business, competition and utilization of trade preferences are the major determinants of export performance of manufacturing industries.
\end{abstract}

Keywords: Export, Performance

DOI: $10.7176 / \mathrm{EJBM} / 11-7-08$

Publication date:March $31^{\text {st }} 2019$

\section{Introduction}

The historical experiences of the world economy shows that countries used different types of polices and strategies taking into account their own resources and contexts, but all have the ultimate objective of attaining industrial development. And, this industrial development requires structural transformation from agriculture to a more productive and complex economic activity such as industry. This implies industrial development matters for sustainable economic development because; it provides high wage jobs, a key to trade deficit reduction, commercial innovation and environmental sustainability (Susan et al, 2012).

In general, industrialization has a significant role in the economic development particularly in fostering of export performance and reduction of unemployment. And, the essential roles played by industrial sector are based on five arguments. First, development arguments: more advanced nations are better industrialized and less developed nations are less industrialized. Second, Employment argument; the industrial sector has more potential to create job opportunities for rapidly growing urban population of developing nations than any other sector. Third, the BOP (Balance of payment) arguments; a developed industrial sector, in general, generates more foreign currency compared to the agricultural sector. That is, industrialization will help to alleviate the BOP problems. Fourth, the linkage argument; if the industrial development directed to use local raw materials it can create strong linkages among different sectors of the economy. This is due to the dynamic nature of the industrial sector which entails externalities in consuming agricultural raw materials, producing consumer and capital good for the economy. Finally, saving argument; the profit margins in the industrial sector are higher than those in agriculture and this may lead to a higher level of saving. (Andualem 2015).

In cognizant of the potential benefits likely to be derived from the industrial sector, in Ethiopia, based on the Growth and Transformation Plan (GTP I and II), the government promises to create favorable conditions for the industrial sector to play a key role in the economy for the sake of ensuring faster and sustainable development of the sector. To this end, particular emphasis is given to expansion and development of micro and small scale enterprises as well as further development of medium and large scale industries (MoFED, 2010).

The industrial sector in Ethiopia includes manufacturing, construction, electricity, water and mining subsectors. Of these subsectors, manufacturing constitutes the second biggest industrial activity in the country, next to the construction subsector (Alemayehu and Tadele, 2004). Hence, the development of the manufacturing subsector is believed to bring about significant change for the industrial sector, and the economy at large.

Given the fact that one of the major objectives for the development of the manufacturing sector (specially the medium and large scale manufacturing industries) is to increase the foreign currency earnings, assessing the determinants export performance of manufacturing industry has always been noticeable issue for developing countries like Ethiopia. Since Ethiopian government paid great attention to FDI (Foreign Direct Investment) in order to inspire its development.

Ethiopian export is dominated by primary products; as a result of which the country faces BOP deficit for the 
fact that prices of primary products are instable and lower as compared to prices of industrial products in the international market. Sisay (2010), states that Ethiopian Merchandise export structure still remains undiversified. On average five commodities; Coffee, Flower, Oil Seeds, Hide and Skins \& Chat account for $78 \%$ of export revenue. The dependence of export revenues on few commodities has made Ethiopia's export performance highly volatile depending on the performance of the major commodities. These products are mainly primary products with fewer linkages in the economy and also declining prices internationally, though there are up swings (Sisay, 2010). Cognizant of this, it is indispensable to increase the export of the manufacturing products as an alternative means of generating foreign currency to overcome the BOP deficit. No matter the fact that export of the manufacturing sector is believed to improve the trade deficit in the international market, it shows a falling trend in terms of its performance. Sisay (2010) has indicated that manufacturing exports are showing a lingering growth in Ethiopia where their share in total exports declines from $14 \%$ in 1981 to $4.6 \%$ in 2004 . Similarly share of manufacturing in merchandise exports declined from $20.5 \%$ in 1981 to $8 \%$ in 2008 .

From this point of view, it is crucial to figure out the prospects of and the major determinants facing the performance of export of manufacturing products in Ethiopia. Hence, this study envisages around investigation of the performance of export of manufacturing sector in Dire Dawa, Ethiopia. In fact there are very few studies that tried to go through such an issue in Ethiopia; however, they focused on the macroeconomic aspects. Keeping in mind previous studies' gaps, this study mainly focuses on the microeconomic aspects of performance of manufacturing industries. Besides, there are no studies in this study area. Therefore, this study was undertaken in Dire Dawa, focusing on medium and large scale manufacturing industries.

\section{Objectives of the Study}

The general objective of this study is to identify determinants of export performance of manufacturing industries in Dire Dawa city Administration. Specifically, this study was conducted:

i. $\quad$ to assess the existing factors of export performance of manufacturing industries in the administration;

ii. to find out the major challenges retarding the production and export performance of the manufacturing industries;

\section{Review of Related Literatures EXPORT PERFORMANCE}

Export performance of a firm reflects a firm-specific behavior in leveraging its resources and capabilities in an international context at a given point of time. Firm export performance is regarded as one of the key indicators of the success of a firm's export operations, and as such, it has been an extensively studied phenomenon. Numerous studies have been conducted pertaining to provide better understanding of the factors (firm- or environmentspecific) and behaviors (e.g., export strategy) that make exporting a successful venture. (Elena 2014).

\section{EXPORT PERFORMANCE DETERMINANTS}

Export performance determinants are generally grouped into internal factors and external factors. The former can be controlled by the firm, unlike the second relating to the external environment (Zou and Stan, 1998; Sousa et al., 2008). According to Zou and Stan (1998), the internal determinants are justified by the resource based theory while the external determinants are justified by the theory of industrial organization. The resource-based theory considers that the firm controls a set of tangible and intangible resources, having the ability to implement strategies aiming at enhancing its efficiency. For this theory, the internal organizational resources are the main determinants of export performance (Zou and Stan (1998). On the other hand, for the theory of industrial organization, the main determinants of export performance are the external factors and the firm's strategies. This theory focuses on the importance of the role of external factors in the firm's strategy, considering that these factors pressure the firm in order to adapt surviving and growth. (Zou and Stan 1998).

According to Sousa et al. (2008), the foreign market characteristics (e.g., environmental turbulence, cultural similarity, market competitiveness, among others) and the domestic market characteristics (e.g. Export assistance and Environmental hostility) are considered external factors. On the other hand, the export marketing strategy (e.g. product, price, promotion, and distribution strategy), the firm's characteristics (e.g. size, age, and international experience), as well as the characteristics of the firm's management (e.g. education, age, and international experience), are considered internal factors. Zou and Stan (1998) also mention two characteristics of the industry (such as, technological intensity and instability).

Several empirical works (e.g., Cavusgil, Zou, and Naidu, 1993; Cavusgil and Zou, 1994) have demonstrated that the degree of marketing program adaptation is influenced by both internal and external factors. A review of the export marketing and standardization literatures reveals that the internal forces affecting the degree of marketing program adaptation include (1) firm characteristics and competencies (Zou and Stan, 1998), (2) management characteristics (e.g., De Luz, 1993; Koh, 1991), (3) management perceptions and attitudes (e.g., Cavusgil, Zou, and Naidu, 1993) and (4) product characteristics (e.g., De Luz, 1993). Other studies in this area show that the degree of marketing adaptation depends externally on (1) the industry (e.g., Seifert and Ford, 1989), 
(2) foreign market characteristics (e.g., Sousa et al., 2008) and (3) domestic market characteristics (e.g., Zou and Stan, 1998).

The importance of the external determinants is supported by the contingency theory, rooted in the structureconduct-performance framework of industrial organization. (Cavusgil and Zou, 1994). This theory argues that a firm must adapt to the external environment pressures in order to survive and prosper. A superior export performance is a result of a firm's successful strategic response to the external factors. (Zou and Stan, 1998).

\section{The Impact of Internal Factors on Export Performance}

This section reviews key conceptual and empirical studies that have analyzed the impact of internal factors on export performance. It is divided into four parts, in which the impact of the following factors on export performance will he discussed: (1) firm characteristics and competencies, (2) management characteristics, (3) management attitudes and perceptions and (4) product characteristics (Zou and Stan, 1998).

\section{Firm Characteristics and Competencies}

Firm characteristics have been identified as possible determinants of export performance. Some studies have shown that from these characteristics, competitive advantages are built and economic rents are realized. There are also other studies that showed that firms of the same industry differ in their performance, enactment of technology policy and corporate strategies, or use of technology (Lefebvre et.al 2001).

1. Firm size: - The relationship of firm size and export is traditionally considered as positive, i.e., "to compete globally, you have to be big" (Lefebvre et. al 2001). According to Lefebvre, larger firms are generally regarded as more capable of bearing the large investments and high risks associated with exporting. The advantages of exporting may not be totally attractive for large domestic firms who might be oriented towards the domestic market and capitalize on domestic monopoly (Lefebvre et. al 2001).

2. Firm age: - Firm age and export may similarly produce conflicting relationships. As the firm matures, it may have accumulated knowledge stock from which to build their capabilities and provide them better leverage to compete in the world market. However, core capabilities can become more rigid and younger firms may be more flexible, aggressive and proactive in catering world demand (Lefebvre et.al2001).

3. Human capital: - Human capital is strongly related with technological capabilities, an aspect that needs to be developed by firms to remain competitive in the export market. This is usually represented by the share of the skilled employees to total employment and/or the number of employees with degrees in either mathematics or science. Neo-technology model suggests a strong and positive relationship between human capital and export propensity because educated and skilled manpower possesses certain abilities that make it easier to establish and maintain certain contacts with the foreign market. On the other hand, Hecksher-Ohlin model predicts that for countries with abundant unskilled labor, investment for skilled labor would be costly and will have a negative effect on exports. (Van Dijk, 2002).

4. Foreign interest in a local firm: - Foreign interest in a local firm and export activities are expected to have positive relationship mainly because of the multinational's (MNE) access to superior production, technology and management know-how which the local firm can acquire. Further, MNEs have sophisticated international networks which facilitate the exporting process. The studies on Indonesian firms validate this hypothesis ((Van Dijk, 2002).

5. Capital intensity: - Capital intensity is often included as a determinant of firm export performance. The Hecksher-Ohlin model predicts that capital-intensive industrialized countries export more while the opposite is expected for labor-intensive developing countries. Another explanation why a more capital intensive firm have higher propensity to export is due to the past innovations and knowledge the capital embodies, reflecting economies of scale (Van Dijk 2002).

Cavusgil and Zou's (1994) investigation of American exporters found that a firm's international competence influences its export performance. Similarly, several studies have established a positive relationship between firm size and export performance (e.g., Christensen, da Rocha, and Gertner, 1987). According to Kaynak and Kuan (1993), as size and export volume increase, there is a sequential and gradual change in terms of export marketing attitudes, and therefore, a strong impact by export size on export sales. Nevertheless, when looking at the percentage of total profit from exporting (an export performance indicator), the same study reveals that smaller companies have a smaller size but employ more people in exporting units. Similarly, a negative relationship between firm size and export performance was also found in other studies (e.g., Das, 1994).

Seifert and Ford (1989) found a positive relationship between firm age/experience and export performance. According to them, overall satisfaction with export performance increases with (1) a firm's export experience of the product line and (2) its overall export experience. Somewhat differently, Kaynak and Kuan's (1993) investigation indicates that younger firms tend to have better profit-ability because they are more willing to adapt. 


\section{Management Characteristics}

Management characteristics have also been correlated with export performance. Both Koh's (1991) study of American exporters and Kaynak and Kuan's (1993) investigation of Taiwanese exporters, assert that the skills of top managers are a key factor in terms of export performance. Other studies also suggest that export performance is influenced by the training of managers in international business (e.g., De Luz, 1993). With regard to the firm's level of export experience, most empirical investigations (e.g., Das, 1994; Madsen, 1989) reveal a positive relationship between export experience and export performance. Similarly, Das (1994) advances that the level of foreign experience influences both export intensity and sales growth.

\section{Product Characteristics}

The impact of product characteristics on export performance is an area where more research has developed. In contrast to De Luz's (1993) findings revealed that for Canadian exporters, product technology has a positive impact on export intensity. De Luz's investigation also indicates that product uniqueness influences export intensity for Canadian exporters.

With regard to the extension of a product line in a foreign market, there have been divergent findings. While Christensen, da Rocha and Gertner (1987) revealed that successful exporters have a widely diversified product line.

The importance of the existence of complementary products in the export market is also expressed by Beamish, Craig and McLellan (1993). Their findings with regard to Canadian exporters reveal the existence of a positive relationship between this issue and export profit and relative export profit.

\section{The Impact of External Factors on Export Performance}

The previous section presented several studies that examined the impact of internal factors on export performance. This section will review empirical studies that have dealt with the analysis of the impact of external factors on export performance. It is divided into three parts which will examine the impact of various external factors: (1) industry, (2) foreign market and (3) domestic market characteristics (Zou and Stan, 1998).

\section{Industry Characteristics}

Over the last decade, many empirical studies investigated around industry characteristics in the exporting context. These include the industry's stability level, predictable changes, speed of change, seasonal/cyclical fluctuations, risk level, competition level and a number of new competitors (Das, 1994). Another factor is the 'line of industry,' a concept introduced by Cavusgil and Zou, 1994. By this, the authors refer to the 'manufacturing complexity' of the industry or the technical know-how involved with products. According to their findings, the higher the manufacturing complexity of Austrian firms, the better their export performance. An industry's technological intensity is also referred to as a key determinant of export performance (Cavusgil and Zou, 1994).

\section{Foreign Market Characteristics}

When comparing the performance of companies that export to developed and developing countries, Sriram and Manu's (1995) empirical investigation reveals that firms that export to developing countries have a better performance than firms that export to developed countries. They suggest that this might be explained by the existence of less competition in developing countries. With regard to Canadian companies, Beamish, Craig and McLellan's (1993) investigation revealed a positive relationship between exporting to Less Developed Countries (LDCs) and export profit. With respect to British exporters, a positive relationship between exporting to LDCs and export intensity was found. In contrast, according to Kaynak and Kuan (1993), high performers must export their product to more industrialized places. They argue that it is possible to achieve a better performance in industrialized countries, due to the existence of more favorable operating conditions in those countries.

\section{Domestic Market Characteristics}

Recent literature (Das, 1994; Zou and Stan, 1998) claims that few investigations exist on the impact of domestic characteristics on export performance. Indeed, most of the existing works in this area have looked at the importance of domestic characteristics for export performance for firms based in LDCs (e.g., Das, 1994). Politico-legal issues in the domestic market, such as changes in export policies and the lack or non-existence of governmental agencies that support export activities (Das, 1994) are key determinants.

The type of competition faced by a firm in the domestic market also affects its export performance. While Madsen's (1989) survey reports that the non-attractiveness of the domestic market influences and domestic market attractiveness (i.e., domestic market potential and market growth) influences export intensity.

\section{The Impact of Marketing Strategy on Export Performance}

As a marketing strategy is composed of several elements (see Zou and Stan 1998), one possible way of narrowing 
down these elements is to look at export performance as an outcome of the degree of marketing adaptation (Shoham, 1996). The degree of marketing program adaptation at the international level involves the manipulation of the marketing mix components (Product, promotion, price and distribution) (Omer, 1986). Thus, this section will discuss the studies that have looked at the impact of the degree of program adaptation on export performance from the traditional 4 Ps perspective.

\section{Product Adaptation}

Degree of product adaptation has received most of the attention in the standardization literature. As with promotion, product adaptation has been researched much more than price and distribution (Rosenbloom, Larsen, and Mehta, 1997; Jain, 1989). Most investigations indicate that export performance is negatively influenced by core product adaptation (e.g., Christensen, da Rocha, and Gertner, 1987; De Luz, 1993). However, with regard to the other indicators, most studies indicate a positive relationship with export performance.

An investigation of American exporters (Cavusgil and Zou, 1994) argues that export performance is influenced by the degree of product adaptation. Similarly, Kaynak and Kuan's (1993) investigation reveals that high performers must adapt their products to the export market and offer wider products lines. Koh's (1991) investigation of American exporters also found that they modify their domestic product line for the export market in order to achieve a higher perceived profitability level than those exporters who use the same domestic product line for export markets. According to Shoham (1996), the adaptation of a number of product lines improves sales and profits margins. Other variables that have been empirically examined in the exporting field, when examining the product adaptation/standardization debate, include: product quality, service, policy, brand name, packaging, styling, appeal, warranty, color, features and design (e.g., Seifert and Ford, 1989; Shoham, 1996).

\section{Promotion Adaptation}

Jain (1989) draws attention to the fact that both promotion and product are aspects of the marketing program that have received more attention than others. According to Jain, nearly half of the studies in the standardization field are concerned with promotion issues, and in particular, with advertising. With regard to the impact of the degree of promotion on export performance, Seifert and Ford's (1989) survey of 65 American exporters indicates that satisfaction levels, in terms of overall performance, are higher for those firms that spend more on advertising, sales promotion, overall promotion, personal selling and publicity/public relations respectively. In contrast, Sriram and Manu's (1995) findings indicate a negative relationship between export performance and overall promotion adaptation.

\section{Distribution Adaptation}

Distribution is one of the marketing mix components ('Ps') where less research has been conducted, and in the particular case of the standardization controversy, has been given particularly little attention (Myers and Cavusgil, 1996; Rosenbloom, Larsen, and Mehta, 1997). As Rosenbloom, Larsen, and Mehta (1997:50) states, relative to other areas of marketing, channels of distribution are given short shrift in the standardization versus adaptation debate. Similarly, with regard to the impact of the degree of distribution adaptation on export performance, there is little research (Zou and Stan, 1998). Beamish, Craig and McLellan (1993) and Shoham's (1996) investigations examine this phenomenon. Beamish et al.'s work reveals that Canadian exporters who select a different distribution channel from that used for the domestic market have a better export profit. Shoham's (1996) study indicates that there is a positive relationship between the degree of adaptation of sales force management and export performance (i.e., sales, profit margins and profit growth).

\section{Price Adaptation}

As Myers and Cavusgil (1996) point out, the impact of export pricing strategies on export performance is a neglected area of research. As with distribution, price has received little attention in international marketing (Myers and Cavusgil, 1996). Furthermore, as there has been little research of pricing at both the international and exporting levels, specific issues in the price area, such as price adaptation/standardization, have received even less attention. Shoham's (1996) investigation advances a positive relationship between price and credit terms, and export profit margins and profit growth.

\section{Method and Materials}

\subsection{Research Design and data of source}

For this study, both quantitative and qualitative information was taken into account. The information gathered was from both primary and secondary data sources. The secondary data was extracted from all concerned organizations such as Trade and Industry Office, Central Statistical Agency, Finance and Economic Development Office, etc. The primary data was collected from all manufacturing sectors of Dire Dawa Administration. Since the researcher was consider all the medium and large scale manufacturing sectors of the study area, my parameters of interest are 
captured as a census of total manufacturing ( 84 manufacturing industries in number) so that the researcher need not have sampling design.

\subsection{Methods of data collection}

The primary data was collected through field instrument such as structured questionnaires (168 questioners for 84 manufacturing industry workers, officers in trade and industry, policy makers and other stake holders) which will direct the type of information to be collected. Each industry will expect to fill 2 questionnaires. To this end, capable field enumerators was recruited and trained. The secondary data was extracted under a comprehensive desk review of the manufacturing sector policies, performance, status, problems etc.

\subsection{Methods of data analysis}

This study was conducted making use of both descriptive, qualitative and quantitative analyses. The descriptive analysis is related to assessment of the performance of export, finding the major challenges for export of the sector. My tools of analyses, in this regard, include simple statistical tools such as percentages, frequency tables, pie charts, bar graphs, Likert type scaling etc.

\section{Results and Discussion}

Table 4.1.Is technologically advanced plant, buildings, assembly lines and machinery are the major factor to reach major export growth targets and to be able to compete, penetrate and grow in overseas markets?

\begin{tabular}{|l|l|l|}
\hline & Frequency & Percent \\
\hline yes & 101 & 93.5 \\
no & 7 & 6.5 \\
Total & 108 & 100.0 \\
\hline
\end{tabular}

Table 4.1 above illustrates that 101(93.5\%) which is the largest population of the respondents replied that technology advanced plant, buildings, assembly lines and machinery are the major factor to reach major export growth and $7(6.5 \%)$ of the respondents were replied that technology, advanced plant, buildings, assembly lines and machinery are not the major factor to reach major export growth.

Table 4.2 how do you rate the quality and quantity of raw material access to your production?

\begin{tabular}{|l|l|l|}
\hline & \multicolumn{1}{|c|}{ Frequency } & \multicolumn{1}{c|}{ Percent } \\
\hline high & 11 & 10.2 \\
moderate & 8 & 7.4 \\
low & 89 & 82.4 \\
Total & 108 & 100.0 \\
\hline
\end{tabular}

Table 4.2 above shows that $89(82.4 \%)$ which is the largest population of the respondents replied that the quality and quantity of raw material access is low, $11(10.2 \%)$ of the respondents were replied high and $8(7.4 \%)$ of the respondents were replied moderate for quality and quantity of raw material access for production.

Table 4.3 In terms of logistics and transportation to import raw materials and to export your product, how do you see the time and procedure they take?

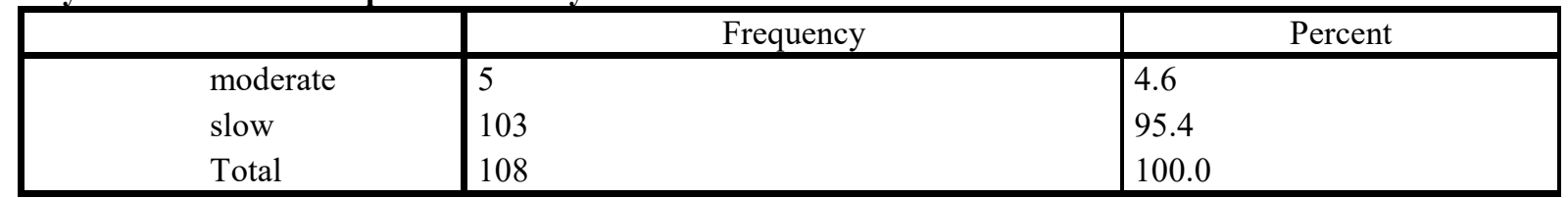

Table 4.3 above illustrates that 103(95.4\%) which is the largest population of the respondents replied that the time and procedure for logistics and transportation taking to import raw materials and to export their products were slow and 5(4.6\%) of the respondents were replied moderate.

Table 4.4 how do you look the availability of manpower on market in specialized areas?

\begin{tabular}{|l|l|l|}
\hline & \multicolumn{1}{|c|}{ Frequency } & \multicolumn{1}{c|}{ Percent } \\
\hline moderate & 16 & 14.8 \\
low & 92 & 85.2 \\
Total & 108 & 100.0 \\
\hline
\end{tabular}

Table 4.4 above illustrates that $92(85.2 \%)$ which is the largest population of the respondents replied that, availability of man power on the market on specialized areas and 16(14.8\%) of the respondents were replied that there is moderate level of opportunity to get man power on the market on specialized areas. 
Tale 4.5 Do you believe the loan system that you got for investment from banks is well- organized and available whenever you want?

\begin{tabular}{|l|l|l|}
\hline & \multicolumn{1}{|c|}{ Frequency } & \multicolumn{1}{c|}{ Percent } \\
\hline yes & 14 & 13.0 \\
no & 94 & 87.0 \\
Total & 108 & 100.0 \\
\hline
\end{tabular}

Table 4.5 above illustrates that $94(87.0 \%)$ of the respondents which is the largest population replied that loan system they got from banks for investment is not well-organized and not available whenever they went and this is due to banks consideration on the issues like tax clearance, customs clearance, delinquency clearance, provision of recently audited statement by approved auditor, restrictions imposed on the bank's credit limits for a single enterprise, government lease value of land and lease values of land from the market for asset valuation. Furthermore there is inadequate use of newer alternative financing systems such as equity finance, leasehold financing and warehouse financing. The rest of the population which accounts $14(13.3 \%)$ replied that there is a well-organized bank loan system and they also said that the can get a loan from banks whenever they want. Table 4.6 does the current exchange rate of the country's currency suitable to enter in the export market?

\begin{tabular}{|l|l|l|}
\hline & \multicolumn{1}{|c|}{ Frequency } & \multicolumn{1}{c|}{ Percent } \\
\hline yes & 8 & 7.4 \\
no & 100 & 92.6 \\
Total & 108 & 100.0 \\
\hline
\end{tabular}

Table 4.6 above illustrates that $100(92.6 \%)$ of the respondents which is the largest portion of the targeted population were replied that the current exchange rate of country's currency is no suitable to enter in the export market and the rest of the respondents which accounts $8(7.4 \%)$ replied that the current exchange rate of country's currency is suitable to enter in the export market.

Table 4.7 is the government gives you an incentive for exporting your product to foreign market?

\begin{tabular}{|l|l|l|}
\hline & \multicolumn{1}{|c|}{ Frequency } & \multicolumn{1}{c|}{ Percent } \\
\hline yes & 14 & 13.0 \\
no & 94 & 87.0 \\
Total & 108 & 100.0 \\
\hline
\end{tabular}

Table 4.7 above indicates that $94(87.0 \%)$ of the respondents from the total targeted population replied that there is no an incentive they received from the government for exporting their products to the foreign market and the rest $14(13.0 \%)$ of the respondents were replied that there is an incentive they received from the government for exporting their products to the foreign market. The respondents commented as a reason is, this is due to unequal incentive support for FDI and local enterprises.

Table 4.8 how do you see the use of internet for accessing commercial information e-procedures from local stakeholders and abroad manufacturers and buyers?

\begin{tabular}{|l|l|l|}
\hline & \multicolumn{1}{|c|}{ Prequency } & \multicolumn{1}{c|}{ Percent } \\
\hline high & 7 & 6.5 \\
moderate & 19 & 17.6 \\
low & 82 & 75.9 \\
Total & 108 & 100.0 \\
\hline
\end{tabular}

Table 4.8 above indicates that $82(75.9 \%)$ of the respondents were replied that there is low use of internet for accessing commercial information e-procedures from local stakeholders and abroad manufacturers and buyers, $19(17.6 \%)$ of the respondents were replied that there is moderate use of internet for accessing commercial information e-procedures from local stakeholders and abroad manufacturers and buyers and the rest of the respondents which accounts $7(6.5 \%)$ were replied that there is high use of internet for accessing commercial information e-procedures from local stakeholders and abroad manufacturers and buyers.

Table 4.9 how do you rate your organization's targets for improving productivity, value addition and diversification?

\begin{tabular}{|l|l|l|}
\hline & \multicolumn{1}{|c|}{ Frequency } & \multicolumn{1}{c|}{ Percent } \\
\hline excellent & 77 & 71.3 \\
good & 17 & 15.7 \\
bad & 14 & 13.0 \\
Total & 108 & 100.0 \\
\hline
\end{tabular}

Table 4.9 above illustrates that $77(71.3 \%)$ of the targeted respondents were replied that there is excellent 
organizational experience for improving productivity, value addition and diversification, $17(15.7 \%)$ of the respondents were replied that there is good organizational experience for improving productivity, value addition and diversification and the rest $14(13.0 \%)$ of the respondents were replied that there is bad organizational experience for improving productivity, value addition and diversification.

Table 4.10 how do you see your products unit price, differentiation, branding and retailing to the foreign market?

\begin{tabular}{|l|l|l|}
\hline & \multicolumn{1}{|c|}{ Frequency } & \multicolumn{1}{c|}{ Percent } \\
\hline suitable & 19 & 17.6 \\
Not suitable & 89 & 82.4 \\
Total & 108 & 100.0 \\
\hline
\end{tabular}

Table 4.10 above indicates that $89(82.4 \%)$ of the respondents among the targeted population were replied that their products unit price, packaging and branding and retailing are not suitable to the foreign market. This is due to the manufactured product exports compete in the international market mainly on price. Accordingly pricing sheets for many products show that export sales are made on a cost plus profit basis. In addition to this, absence of differentiation in the export market or unattractive presence of packages with brands results the products exported do not trigger any noteworthy recall in customers' minds. Plus products exported are sold to an intermediate buyer: there is very little retailing in any export market either physically or over the internet. The rest of the respondents which accounts $19(17.6 \%)$ were replied that that their products unit price, packaging and branding and retailing are suitable to the foreign market.

Table 4.11 what is your idea about the easy of doing business and conduciveness of the environment to make your business competitive?

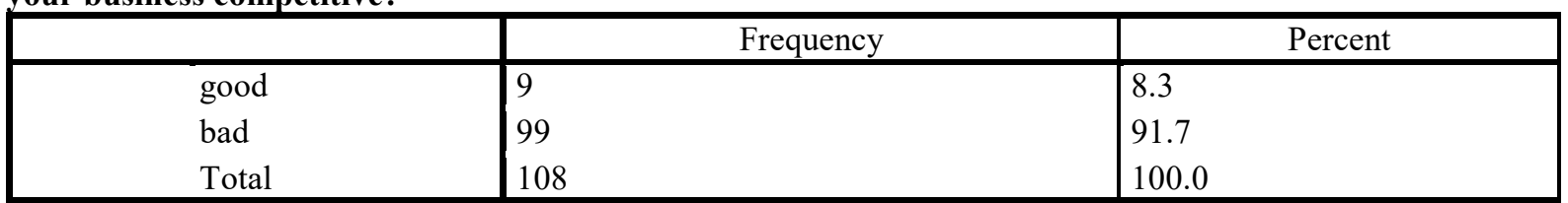

Table 4.11 above illustrates that $99(91.7 \%)$ of the respondents which is the largest percent of the targeted population were replied that there is bad environment for doing their business easily and to become competitive in the market. The respondents' reason out for this problem is that, in order to start a domestic business a large number of steps are needed, a considerable amount of time spent and significant costs incurred. The rest of the respondents which accounts $9(8.3 \%)$ were replied that there is good environment for doing their business easily and to become competitive in the market.

Table 4.21 what is your idea about the growth of competitiveness of large and small enterprises for exporting market?

\begin{tabular}{|l|l|l|}
\hline & Frequency & Percent \\
\hline Significant for small enterprises and insignificant for large enterprises & 82 & 75.9 \\
Insignificant for both large and small enterprises & 26 & 24.1 \\
Total & 108 & 100.0 \\
\hline
\end{tabular}

Table 4.21 above indicates that $82(75.9 \%)$ of respondents were replied that the growth of competitiveness of large and small enterprises for exporting market is significant for small enterprises and insignificant for large enterprises and the rest of the respondents which accounts 26(24.1\%) were replied that the growth of competitiveness of large and small enterprises for exporting market is insignificant for both large and small enterprises.

Table 4.12 what is your opinion in utilization of existing trade preference by foreign countries in terms of procedural reasons including documentation of rules of origin?

\begin{tabular}{|l|l|l|}
\hline & \multicolumn{1}{|c|}{ Prequency } & Percent \\
\hline moderate & 16 & 14.8 \\
low & 92 & 85.2 \\
Total & 108 & 100.0 \\
\hline
\end{tabular}

Table 4.12 above illustrates that $92(85.2 \%)$ of the respondents which is the largest percent of the targeted population replied that the existing trade preference by foreign countries in terms of procedural reasons including documentation of rules of origin is low and the rest $16(14.8 \%)$ of the respondents were replied that the existing trade preference by foreign countries in terms of procedural reasons including documentation of rules of origin is moderate. 


\section{Conclusion and Recommendation}

Building of Physical Capital: In order to reach major export growth targets and to be able to compete, penetrate and grow in overseas markets, it is necessary to manufacture quality products in substantial quantities competitively. For this physical capital, in the form of technologically advanced plant, buildings, assembly lines and machinery are required, designed to operate at a scale that can produce major product volumes.

Raw Material Supplies: The quality and quantity of raw material supply is inadequate for almost all products of the manufacturing export sector except cement factory. Access to raw material is inadequate and often delayed for most enterprises like detergent and flour factories and raw material import procedures are also long. Also insufficient linkages between raw material suppliers and manufacturing industries are mentioned as a problem for accessing raw materials on the required quality and quantity.

Logistics and Transportation: The procedure and time required for the transportation and logistics for importing raw materials and exporting products are too long. The cost of logistics on Djibouti port due to penalties of a time to keep containers and lack of better and efficient administration on Dire Dawa dry port creates congestion of containers and this makes the industries bored on importing raw materials and exporting goods.

Building of Human Capital: Educated and Skilled Work Force: The availability of a broad base of human capital is essential for the sustainability of growth in a competitive market place. Depth of universal primary education and literacy levels ensure that on-the-job learning and cognitive skills of the workforce are present and advanced. Investing enterprises find it easier to upgrade the skills of such workers, to use new and advanced technology and to continuously improve productivity for the continuous growth of efficiency and competitiveness. But due to the shortage of skilled man power on the market it's very difficult to hire the required skill needed by the organization. It's obvious that, to solve this solution the organization must adopt the development of skills of workers available in the organization but most of the organizations haven't such an experience on developing the skills of their workers.

Loan from Banks: A major constraint especially to domestic enterprise growth is the system of granting of loans by banks. When considering a loan application, the banks consider not only issues like business performance, its credit profile and management capabilities but also several compliance requirements including tax clearance, customs clearance, delinquency clearance, provision of recently audited statement by approved auditor, restrictions imposed on the bank's credit limits for a single enterprise, government lease value of land and lease values of land from the market for asset valuation. Furthermore there is inadequate use of newer alternative financing systems such as equity financing, leasehold financing and warehouse financing;

Rate of Exchange: The rate of exchange has a direct bearing on export volumes and value of exports. A strong over valued local currency hurts the entire export sector including the manufactured export sector. A recent study has indicated that the real effective exchange rate in Ethiopia has appreciated which makes exports less competitive.

Interventions for Exports: Incentives: Established local enterprises are equal in terms of benefits and entitlements with FDI enterprises which operate under the voucher scheme, the effects of the incentives on the ground are not equal. Unless they make new large investments themselves, domestic export enterprises compete at a disadvantage with FDI enterprises in the same destination export market.

Use of the Internet: Access to Commercial Information; e-procedures: Enterprises have established and regular procedures for working with the government, banks, customs and other authorities. These procedures are carried out by physically filing papers. Though they were efficient earlier they involve considerable cost and time at present as the volume of transactions has grown manifold over the years with the growth of the economy. This is due to lack of an experience for using computerized and internet based system.

Productivity improvement, Value addition and Diversification: value addition and diversification in processes and products secure higher export prices that are vital for the export growth that has been targeted. The experience of industries in Dire Dawa is on a good position for improving productivity through value adding and diversification.

Unit Prices, Differentiation, Branding, and Retailing: Currently some Dire Dawa's industries manufactured product exports compete in the international market mainly on price. Accordingly pricing sheets for many products show that export sales are made on a cost plus profit basis. Also, in the absence of differentiation in the export market or of the presence of brands, the products exported do not trigger any noteworthy recall in customers' minds; products exported are sold to an intermediate buyer: there is very little retailing in any export market either physically or over the internet.

Ease of Doing Business: Conduciveness of the Business Environment: At present to start a domestic business a large number of steps are needed, a considerable amount of time spent and significant costs incurred. This is detrimental to starting a business; the environment is generally not conducive to business growth.

Competition: The major export manufacturing segments in Dire Dawa are dominated by some large domestic and FDIs enterprises which generate a bulk of the exports. The rest are smaller enterprises which together account for a small percent of the total exports; also, there is insignificant growth in the number of domestic export enterprises.

Utilization of Trade Preferences: There is relatively low utilization of existing trade preferences by exporters in the 
foreign markets due to procedural reasons including documentation relating to rules of origin.

\section{Recommendation}

Increase Physical Capital; Investments: Attract foreign and domestic investments in manufactured products, especially investments that create physical capital and involve the latest technology and processes; ensure investor confidence through continued macroeconomic stability, low inflation, investor protection arrangements; set targets for investment.

Ensure Raw Material Supplies: Set up a Raw Material Information and Supply Enterprise: Ensure raw material supplies particularly for the domestic export enterprises. Reduce the procedures for importing raw materials and create linkage between raw material suppliers and industries.

Provide Better Logistics, Transportation: Reduce costs of logistics further by avoiding penalties/demurrage of vessels, decongesting and better administering Dire Dawa Dry Port, increasing free time and deceasing turnaround time for containers; decreasing congestion at Dire Dawa Dry Port, avoiding penalties/demurrage of vessels and by increasing the free time for containers.

Improve Human Capital: Educate and Empower: set up National or Regional Skills Development Corporation: To meet the substantial demand for skills that will arise from (a) GTP-II targets, (b) expansion plans of existing FDI enterprises and (c) from fresh investments, a private sector- administration forum needs to be set up to supplement the skill building work currently being done by many enterprises. Besides, a National or Regional Skills Development Corporation will be required to be set up to prepare new entrants and coordinate inclusive skill building at the national or regional level covering all geographic zones. To reduce costs, skill development inputs will need to be given by private sector professional skill developers.

Review Loan from Banks: Review bank and compliance conditions for granting of credit to domestic export enterprises including for SMEs, especially for working capital; the conditions that need to be reviewed should include bank rules, DBE and NBE requirements, law enforcement for bad loan recoveries and social issues involved in resale of property.

The performance track record of export manufacturing enterprises should be designated as the major criterion for granting of credit. Ensure more autonomy for banks and greater use alternative financing systems like equity financing, lease financing and warehouse receipt financing; create a more enabling environment for their use. Improve NBE's capacity to forecast financial flows; allocate foreign exchange to offset seasonal fluctuations of export earnings;

Review the Rate of Exchange: A strong local currency hurts the entire export sector including the manufactured export sector. However any decision in this area needs to take into consideration Ethiopia's past experiences with devaluation when exports had not increased significantly and to consider its likely impact on major construction projects that are currently underway which involve very substantial imports.

Review Interventions and Incentives for Exports: Extend Income Tax Exemption Periods: Support Accessories Manufacture; e-Retailing: Encouragement to all enterprises to register and claim export incentives; designate as Accessories Economic Cooperators enterprises which manufacture at least $25 \%$ of their accessories for export; provide preference to them in foreign exchange allocation; provide free skill building for all exporters; put in place systems that facilitate customs to easily segregates export and domestic outputs; ensure transparency of procedures and valuations by customs.

Use of the Internet; Access to Commercial Information; e-Procedure: introduction of on-line systems are essential for all export procedures including banking and trade finance, filing of shipping papers with customs, customs appeals; there is need for e-linking with Djibouti Customs; e-tracking cargo movement and handling at Dire Dawa Dry Port; e-information on raw materials availability and introduce legislation for recognition of esignatures;

Targets for Productivity, Value addition and Product diversification: In the GTP II period growth and its sustainability will assume major significance; greater industry awareness of this as well as the need for shifting from factor driven exports to efficiency driven, value added and diversified exports are needed. Targets are required to be set product group wise particularly for the domestic export manufacturing sector through a process of consultations, for value addition, productivity and product diversification.

Unit prices, Differentiation, Branding and Retailing: In GTP II growth and sustainability of exports will assume major significance; this and the greater awareness of the need for shifting from factor driven exports to efficiency driven exports would be vital; exports need to be value added, branded and diversified and retailed for better prices; set targets for value addition, diversification and productivity according to product groups; facilitate access to packaging materials; encourage technology tie-ups; hold overseas brand building events; support licensing, trade mark initiatives and export buy-back arrangements.

Ease of Doing Business, Conduciveness of the Business Environment: There is a need to reduce the number of steps, the time and the cost of starting a business; costs can be totally removed for SMEs; there is need for decongesting Dire Dawa Dry Port; better customs working including review of duty database and appeals system; increasing on-line 
filing of papers; review of customs procedures: more risk management to reduce delays; provision of single window facility; e-linking between Djibouti to ERCA. Basically the logistics sector must grow at the same rate as the industry sector.

Competition: Growth in the number of smaller enterprises can be limited by several factors including the dominance in the market of a few large domestic and FDIs; awareness of their impact on the overall growth and survival of smaller domestic export enterprise and SMEs need be raised; to increase competitive practices, general transparency and simplification of redress procedures and provide more investor protection are important.

Utilization of Trade Preferences: There is need to improve utilization of trade preferences by exporters to the foreign markets by improving their compliance with regulations including rules of origin; to increase regional trade with other African countries.

\section{Reference}

Alemayehu Seyoum Taffesse and Tadele Ferede (2004): "The Structure of Ethiopian Economy - A SAM-based Characterization"; Background paper for the Ethiopia Country Economic Memorandum: World Bank,

Andualem Girma (2015): "Determinants of export performance and employment of labor in large and medium scale manufacturing industry of Ethiopia: An ARDL cointegration approach" MSc thesis, Addis Ababa University.

Beamish, P. W., Craig, R., \& McLellan, L. (1993). "The performance characteristics of Canadian versus UK exporters in small and medium sized firms". Management International Review, 33(2), 121-137.

Cavusgil, S. T., \& Zou, S. (1994). "Marketing strategy-performance relationship: An investigation of the empirical link in export market ventures". Journal of Marketing, 58(January), 1-21.

Cavusgil, S. T., Zou, S., \& Naidu, G. M. (1993). "Product and promotion adaptation in export ventures: An empirical investigation”. Journal of International Business Studies, 24(3), 479-506.

Christensen, C. H., da Rocha, A., \& Gertner, R. K. (1987). “An empirical investigation of the factors influencing exporting success of Brazilian firms". Journal of International Business Studies, 18(Fall), 61-77.

Das, M. (1994). "Successful and unsuccessful exporters from developing countries”: Some preliminary findings. European Journal of Marketing, 28(12), 19-33.

De Luz, M. (1993). "Relationship between export strategy variables and export performance for Brazil-based manufacturers". Journal of Global Marketing, 7(1), 87-110.

De Luz, M. (1993). "Relationship between export strategy variables and export performance for Brazil-based manufacturers". Journal of Global Marketing, 7(1), 87-110.

Elena 2014, "Determinants and measures of export performance - comprehensive literature review," JCEBI, Vol.1 pp. 2

FDRE, MoFED (2010): “Growth and Transformation Plan”; Volume I: Main Text; Ministry of Finance and Economic Development, Addis Ababa.

Jain, S. C. (1989). "Standardization of international marketing strategy": Some re-search hypotheses. Journal of Marketing, pp 70-79.

Kaynak, E., \& Kuan, W. K.-Y. (1993). "Environment, strategy, structure, and performance in the context of export activity": An empirical study of Taiwanese manufacturing firms. Journal of Business Research, 27(1), 3349.

Koh, A. C. (1991). "Relationship among organizational characteristics, marketing strategy and export performance”. International Marketing Review, 8(3), 46-60.

Lefebvre, Elisabeth and Louis A. Lefebrve (2001)."Innovative Capabilities as Determinants of Export Performance and Behavior: Alongitudinal Study of Manufacturing SMEs" in Innovation and Firm Performance: Econometric Explorations of Survey Data, Palgrave (MacMillan Press), London et. Basingstoke.

Madsen, T. K. (1989). "Successful export management": Some empirical evidence. International Marketing Review, 6(4), 41-57.

Myers, M. B., \& Cavusgil, S. T. (1996). “Export pricing strategy-performance relationship”: A conceptual framework. Greenwich, Conn: JAI Press.

Omer, H. M. K. (1986). "Standardization versus adaptation: marketing strategy for the less developed countries". Unpublished doctoral dissertation, UWIST, Wales.

Rosenbloom, B., Larsen, T., \& Mehta, R. (1997). "Global marketing channels and the standardization controversy”. Journal of Global Marketing, 11(1), 49-64.

Seifert, B., \& Ford, J. (1989). “Are exporting firms modifying their products, pricing and promotion policies?”. International Marketing Review, 6(6), 53-68.

Shoham, A. (1996). “Marketing-mix standardization: Determinants of export performance”. Journal of Global Marketing, 10(2), 53-73.

Sisay Menji (2010): Export Performance and Determinants in Ethiopia, MPRA, paper no, 29427/ March 2011. 
Sousa, C., Martínez-Lopez, F. and Coelho, F. (2008), "The determinants of export performance: a review of the research in the literature between 1998 and 2005”, International Journal of Management Reviews, Vol. 10 (4), pp. 343-374.

Sriram, V., \& Mann, F. A. (1995). “Country-of-destination and export marketing strategy”: A study of US exporters. Journal of Global Marketing, 8(3/4), 171-190.

Susan H., Timothy K., and Howard W., (2012), “Why does manufacturing matter? Which manufacturing matters? A policy frame work.

Van Dijk, Michiel (2002). “The Determinants of Export Performance in Developing Countries”: The Case of Indonesian Manufacturing. Working Paper 02.02, Eindhoven Centre for Innovation Studies, The Netherlands.

Wernerfelt, B. (1984), “A resource-based view of the firm Strategic Management”, Journal.5 (2): 171-180.

Zou, S. and Stan, S. (1998), "The determinants of export performance: a review of the empirical literature between 1987 and 1997”, International Marketing Review, Vol. 15 (5), pp. 333-356. 